\title{
ポリカーボネート板の疲労き裂進展の板厚依存性
}

\author{
白 石 哲 郎* 荻 山 博 之** 佃
}

\section{Specimen Thickness Dependence of Fatigue Crack Propagation in Polycarbonate Plates}

\author{
by \\ Tetsuro ShIRAIShI ${ }^{*}$, Hiroyuki OgIYAMA ${ }^{* *}$ and Hitoshi TsukudA ***
}

\begin{abstract}
The effect of the specimen thickness on the fatigue crack propagation in polycarbonate plates was investigated. Fatigue cracks were propagated under axial load conditions with constant amplitude loading, a single peak overload and two-step loading. The crack propagation rates both on the surface and in the interior of the specimen were measured. The crack closure behavior and the appearance of fracture surface were also examined. The fatigue crack propagation rate, $\mathrm{da} / \mathrm{dN}$, under constant amplitude loading increased with increasing specimen thickness at low $\Delta \mathrm{K}$ levels. The crack closure behavior was not appreciably affected by the specimen thickness. The measurements of shear lip width on the fracture surface indicate that the thickness dependence of $\mathrm{da} / \mathrm{dN}$ is closely related with the formation of shear lips. The crack extension during a single peak overload was larger in the thick specimen. The fatigue crack retardation after the peak overload was more marked in the thin specimen, which was similar to the case of stress decrease under two-step loading. These results can also be understood in terms of the contribution of shear lips to fatigue crack propagation.
\end{abstract}

Key words : Polycarbonate, Fatigue crack propagation, Specimen thickness, Shear lip, Single peak overload, Two-step loading

\section{1 緒}

エンジニアリングプラスチックス（エンプラ）あるい はスーパーエンジニアリングプラスチックス（スーパーエ ンプラ）と呼ばれる高性能高分子材料は，軽量構造部材 としての積極的な活用が期待されるが，その際には耐疲 労性を十分把握しておく必要がある. 従来この種の材料 の耐疲労性は主として一定荷重振幅下の疲労限度やき裂 進展抵抗を測定して検討されてきた.1)しかしながら，実 用の各種機器が受ける負荷は複雑な変動荷重である場合 が多いことを考えると，使用状況に応じたより合理的な 評価を下すためには，種々の変動荷重下に扔ける挙動の 把握も不可欠である。このような観点から，筆者らはこ れまで，代表的なエンプラの一つであるポリカーボネー 卜（以下，PC) の板状試験片を用いて，一定荷重振幅下 のみならず単一過大荷重下や二段二重変動荷重下の疲労 き裂進展挙動も調べ，いくつかの知見を得てきた. ${ }^{2}$ 〜 )

ところで，一般に板状試験片の場合，試験片表面層に は平面応力型のせん断縁 (shear lip) が形成され，乥れは き裂進展に対する抵抗として働く. ${ }^{6}$ ししたがって，せん断 縁の形成は試験片全体のき裂進展挙動を左右し，元れに よって板厚効果が現れる。 せん断縁の発生は材料の種類 により異なるが，PCの場合には，比較的容易にそれが 形成されるため，例えば破壊じん性值の板厚依存性がか なり顕著に現れることが知られている? ${ }^{7}$ 一方, 疲労き裂
進展に対する板厚効果については, 若干の検討例 ${ }^{8)}$ はあ るもののな打十分とは言えず，とくに変動荷重下の場合 に関する情報はほとんど得られていない．

そこで本研究では，数種の板厚の PC 予き裂材を用い， 一定荷重振幅下，単一過大荷重条件下扰よび二段二重変 動荷重下の疲労き裂進展挙動を調べることにより，これ らの挙動に及ぼす試験片板厚の影響を検討した。

\section{2 材料および実験方法}

実験に用いた材料は，板厚 $3 \mathrm{~mm}, 5 \mathrm{~mm}$ および $8 \mathrm{~mm}$ の市販の PC 透明板（タキロン PC-1600）である. 各材 料の引張性質（負荷速度 $1 \mathrm{~mm} / \mathrm{min}$ ）は, Table Iに示 すようにほぼ同程度である。素材から幅 $50 \mathrm{~mm}$ ，長さ $180 \mathrm{~mm}$ の短冊状試験片を切り出し, 片側中央部に糸の こおよび鋭利な刃で深さ 約 $2.5 \mathrm{~mm}$ の予き裂を設けた 後，実験に供した。実験には島津サーボペット Lab-5 型 引張圧縮疲労試験機を用い, 応力比 $R=0$ のもとで, 一 定荷重振幅試験，単一過大荷重試験および二段二重変動 荷重試験を行った。繰返し速度は $1 \mathrm{~Hz}$, 雾囲気温度は約 $25{ }^{\circ} \mathrm{C}$ である. Fig. 1 に単一過大荷重試験および二段二重 変動荷重試験の荷重負荷方法を示す。単一過大荷重試験 における過大荷重比 $r\left(=\sigma_{2} / \sigma_{1}\right)$ は 2.0 および 2.5 とし た。ここで， $\sigma_{1}$ は基準繰返し応力， $\sigma_{2}$ は過大応力であ る。過大応力の負荷は，き裂長さが約 $4 \mathrm{~mm}, 7 \mathrm{~mm}$ およ び $10 \mathrm{~mm}$ となった時点で手動（約 $0.1 \mathrm{~Hz} ） に よ り$ 行った。

$\dagger \quad$ 原稿受理 平成 11 年 6 月 3 日 Received June 3,1999

* 正会員 愛媛大学工学部機能材料工学科 ₹790-8577 松山市文京町, Dept. of Mater. Sci. Eng., Ehime Univ., Bunkyo-cho, Matsuyama, 790-8577

** 正会員 愛媛大学工学部機械工学科 广790-8577 松山市文京町, Dept. of Mech. Eng., Ehime Univ., Bunkyo-cho, Matsuyama, 790-8577

*** 愛媛大学工学部機械工学科 T790-8577 松山市文京町, Dept. of Mech. Eng., Ehime Univ., Bunkyo-cho, Matsuyama, 790-8577 
Table I . Tensile properties of materials.

\begin{tabular}{cccc}
\hline $\begin{array}{c}\text { Thickness } \\
(\mathrm{mm})\end{array}$ & $\begin{array}{c}\text { Young's } \\
\text { modulus } \\
(\mathrm{GPa})\end{array}$ & $\begin{array}{l}\text { Yield } \\
\text { stress } \\
(\mathrm{MPa})\end{array}$ & $\begin{array}{c}\text { Elongation } \\
(\%)\end{array}$ \\
\hline 3 & 2.4 & 62.7 & 68 \\
5 & 2.3 & 62.7 & 90 \\
8 & 2.3 & 62.5 & 70 \\
\hline
\end{tabular}

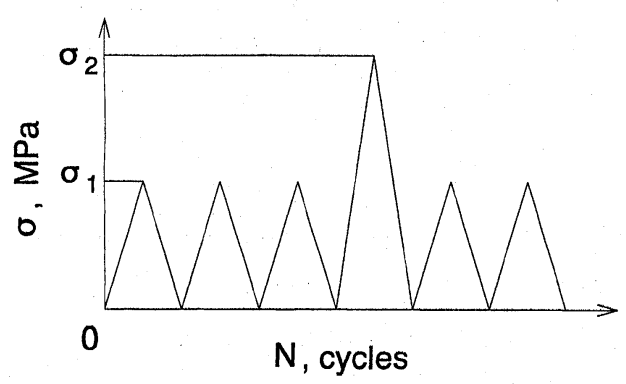

(a) A single peak overload

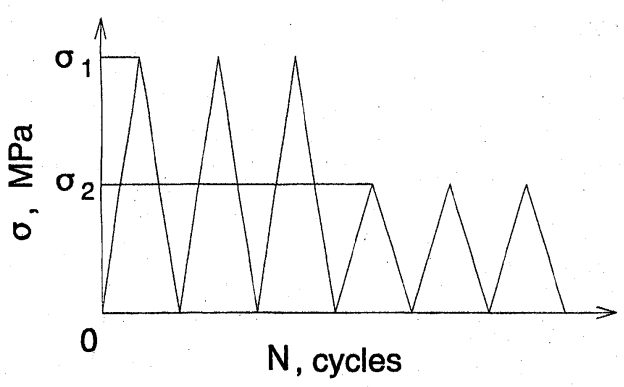

(b) Two-step loading

Fig. 1. Load sequences for overload tests.

二段二重変動荷重試験では, 高応力振幅から低応力振幅 へ変動する, いわゆる応力下降試験を実施し, その場合 の応力下降率は種々の值とした。 き裂長さの測定には読 み取り顕微鏡を用い, 焦点位置を変化させることにより 試験片表面および内部のき裂先端位置を同時に読久取っ た. 応力拡大係数 $K$ 值の計算には試験片つかみ部の拘束 条件を考慮した片側き裂を有する帯板の一様引張りの式 9)を用いた．また，き裂開閉口挙動の測定には金属材料 でよく用いられるひずみゲージによる方法 ${ }^{10)}$ を採用した. すなわち, き裂先端からわずか後方のき裂縁直下に貼り 付けたひずみゲージ（ゲージ長さ $0.2 \mathrm{~mm}$ ）により検出さ れるひずみと荷重の線図を求め，その折れ曲がり点から き裂開口応力 $\sigma_{o p}$ を決定した.

\section{3 実験結果および考察}

\section{$3 \cdot 1$ 一定荷重振幅下のき裂進展挙動}

読み取り顕微鏡による疲労き裂進展挙動の観察による と, き裂はまず試験片内部で進展を開始し, ある程度進 展した後にはじめて表面層でも進展を開始する。その後 のき裂は常に内部で先行し，表面層でのき裂を引きづる ようなかたちで進展を続ける。内部でのき裂の先行量は 繰返し数の増加とともに増加するが，ある段階以降はほ ぼ一定となる。また, 板厚の厚い試験片ほどその先行量
が大きい，このようなき裂進展挙動を考慮して，本研究 では試験片表面と内部でのき裂長さの平均值を用いてき 裂進展挙動を検討した。

Fig. 2 は, 各板厚試験片について得られた一定荷重振 幅下の疲労き裂進展速度 $\mathrm{da} / \mathrm{dN}$ と応力拡大係数幅 $\Delta K$ の 関係を示したものである. $\mathrm{da} / \mathrm{dN}$ は，とくに低 $\Delta K$ 域に おいて板厚の減少とともに低下する傾向が認められる。 從来報告されている G. Pitman らの結果 ${ }^{8)}$ でも類似な板 厚依存性が得られているが，彼らの結果に比べると本実 験の場合には，高 $\Delta K$ 領域での板厚依存性が小さい.

一般に, 金属材料における疲労き裂進展はき裂開閉口 挙動 ${ }^{11)}$ に強く支配されることが知られている。一方，高 分子材料の場合にはこの種のき裂閉口に関する情報が少 なく必ずしも十分明確ではないが，筆者らのこれまでの 測定によると少なくとも試験片表面ではき裂閉口が生じ, この閉口挙動と痩労き裂進展の応力比依存性がある範囲

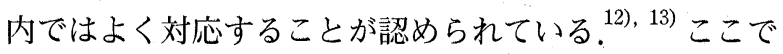
は，このようなき裂開閉口挙動と上述の板厚効果との関 係を確認するため, き裂開口応力の測定を行った. Fig. 3 は, 各板厚試験片のき裂開口応力の測定結果から求め たき裂開口比 $\mathrm{U}\left(=\left(\sigma_{\text {max }} \sigma_{o p}\right) / \Delta \sigma\right)$ の值を比較したもので ある。ここで， $\sigma_{\max }$ は繰返し最大応力， $\sigma_{o p}$ はき裂開口 応力, $\Delta \sigma$ は応力幅を示す. 眓より, いずれの板厚の場合 もU值はほぼ一定の值（約 0.8）を示すことがわかる. このように，き裂開口比が板厚の影響をほとんど受けな いことから, da/dN の板厚依存性はき裂開閉口挙動によ るものではないことが推察される.

緒言でも述べたように，破壊じん性值の板厚効果につ いては, 試験片表面層に形成される平面応力型のせん断 縁の大きさが密接に関係していると言われて抢り，その 板厚効果は, 板厚に対するせん断縁寸法の割合の観点か ら説明されている。包ここでは，以上のような破壊じん性 試験で得られている知見を参考として，せん断縁の観察 を行った. Fig. 4 は，破面上に形成されたせん断縁の幅 $\mathrm{S}$ の板厚 $\mathrm{t}$ に占める割合 $2 \mathrm{~S} / \mathrm{t}$ の測定結果である.困より,

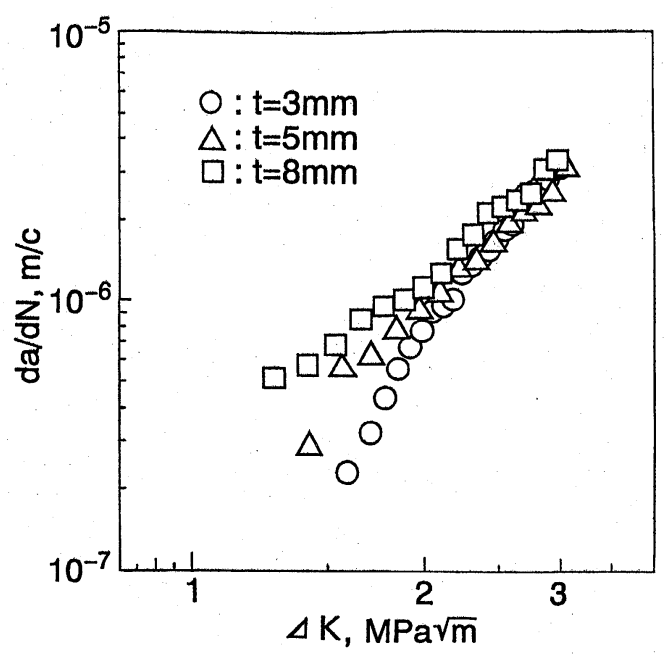

Fig. 2. Effect of specimen thickness on $\mathrm{da} / \mathrm{dN}$ under constant amplitude loading. 


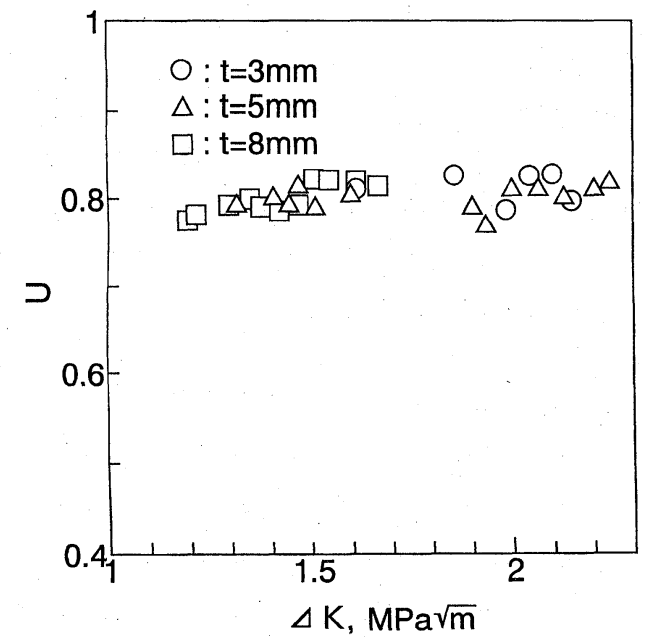

Fig. 3. Effect of specimen thickness on fatigue crack closure.

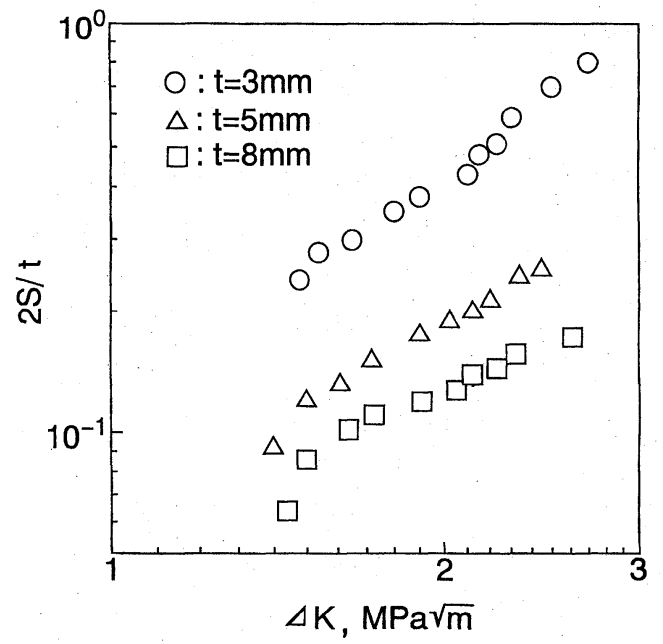

Fig. 4. Effect of specimen thickness on shear lip formation.

$2 \mathrm{~S} / \mathrm{t}$ は板厚の減少とともに増大していることがわかる. 平面応力型のせん断縁の部分は平面ひずみ型の試験片中

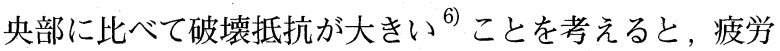
き裂進展抵抗についても，破壞じん性の場合と同様に， 2S/t の大きさが重要な役割を果たしているものと思われ る. 前述のような $\mathrm{da} / \mathrm{dN}$ の板厚依存性は，このようなせ ん断縁の形成挙動に起因しているものと理解される。

\section{$3 \cdot 2$ 単一過大荷重によるき裂進展の加速および遅延 挙動}

高分子材料の疲労き裂進展に及ぼす過大荷重の影響に 関する研究は, 金属材料の場合に比べると数少ないが, 従来からいくつか報告されている. ${ }^{14) ~} 17$ 筆者らもこれま で，いくつかの高分子材料を用いて，疲労き裂進展に及 ぼす単一過大荷重の影響を調べ，過大荷重負荷時のき裂 進展の著しい加速打よび負荷後の遅延に関する若干の知 見を得てきた。 ${ }^{2), 4), 5), 12)}$ Fig. 5 は，それらの加速扰よび遅 延現象を模式的に示したものである. 図中の O.L. は過大 荷重の負荷， $\Delta a_{\text {O.L. }}$ は過大荷重負荷時に生じるき裂進展

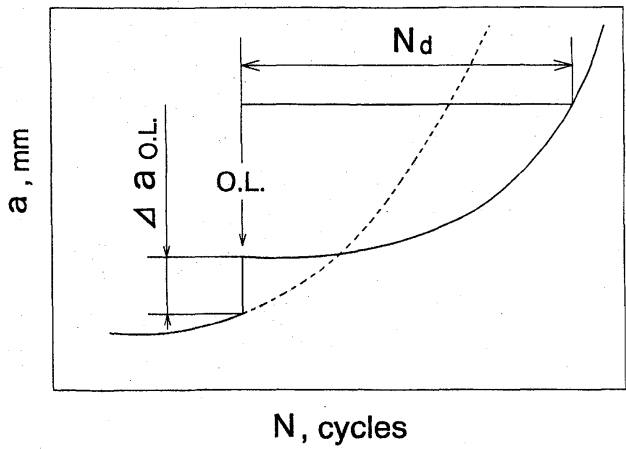

Fig. 5. Schematic illustration for crack acceleration and retardation due to a single peak overload for polymers.

量（この進展量は一定荷重振幅下のき裂進展速度に比べ てきわめて大きいため，過大荷重による加速と呼ばれて いる）, $N_{d}$ は過大荷重負荷後のき裂進展の遅延が続く繰 返し数（遅延繰返し数）である。ここでは, 板厚 $3 \mathrm{~mm}$ および $8 \mathrm{~mm}$ の試験片を用いて，このような加速および 遲延挙動に及ぼす板厚の影響を検討した。なお，基準応 力 $\sigma_{1}$ の值は, 板厚 $3 \mathrm{~mm}$ 打よび $8 \mathrm{~mm}$ の試験片に対して, それぞれ $11.8 \mathrm{MPa}$ および $7.8 \mathrm{MPa}$ とした。

単一過大荷重負荷によるき裂進展の加速現象について は，金属材料の場合にも認められているが，とくに PC のような非晶性高分子材料の場合には現象がきわめて顕 著であるため, 疲労破面の光学顕微鏡観察においてこの 進展域を十分確認できる. ${ }^{2)} \mathrm{Fig} .6$ は，破面上で測定した 加速進展量 $\Delta a_{\text {O.L. }}$ の板厚依存性を示したものである。こ こで, $K_{\text {O.L. }}$ は過大応力に基づく応力拡大係数であり, 加 速進展量およびき裂長さとしては板厚中央部と表面との 中間領域の数ヶ所で測定した平均値を用いた。図からわ かるように, この加速進展量は，一定荷重振幅下のき裂 進展速度の場合と同様に，板厚の薄い場合の方がより小 さい值となった。このような結果に対してもせん断縁の 形成挙動が関連しているものと思われる。すなわち，平 面応力型の塑性域によって形成されるせん断縁がき裂進

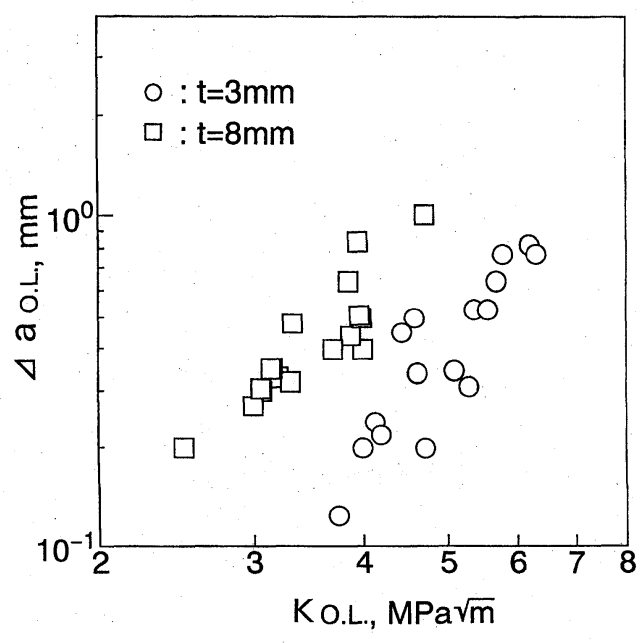

Fig. 6. Effect of specimen thickness on the crack extension during a peak overload. 
展抵抗となるため, せん断縁が板厚の大部分を占める薄 板の方がより少ないき裂進展量となり，このような板厚 依存性が生じたものと推察される，なお，筆者らは前報 ${ }^{5)}$ に打いて, この種の加速進展量は, 試験片内部ではほぼ 一定であるが, 表面のせん断縁近傍で著しく減少すると いう観察結果を報告した. この観察結果も, せん断縁が き裂の加速進展に対して大きな抵抗となっていることを 示唆している.

Fig. 7 は, 単一過大荷重負荷後に生じるき裂進展の遅 延挙動に及ぼす板厚の影響を示したものである。この結 果は, き裂長さが約 $7 \mathrm{~mm}$ の時点（両板厚試験片とも $\mathrm{da} / \mathrm{dN} \fallingdotseq 8 \times 10^{-7} \mathrm{~m} / \mathrm{c}$ のき裂進展速度領域）で過大荷重 を負荷した場合のものであるが, 図より, 薄い試験片の 方が遅延繰返し数はより大きく, また同一板厚の場合, 試験片表面の遅延繰返し数は内部のそれより大きいこと がわかる。この板厚依存性は, とくに $r=2.5$ の場合に 顕著である。これらの遅延挙動の板厚依存性や試験片表 面と内部での挙動の違いに対しても, き裂進展抵抗の高 いせん断縁の形成挙動が密接に関係しているように思わ れた. なお, 金属材料の場合にも, 本研究で得られた結 果と同様な遅延挙動の板厚依存性が報告されている. ${ }^{10), 18)}$

\section{$3 \cdot 3$ 二段二重変動荷重下のき裂進展の遅延挙動}

高分子材料の二段二重応力下降試験においても応力下 降直後にき裂進展の遅延が生じることはすでに報告した 通りである. ${ }^{3)}$ ここでは, この場合の遅延挙動に対する板 厚効果を検討した。

Fig. 8 およびFig. 9 は，それぞれ，板厚 $3 \mathrm{~mm}$ および $8 \mathrm{~mm}$ の試験片について, 二段二重応力下降試験におけ るき裂進展の遅延挙動を示したものである. 図中の $\Delta N$ は高応力 $\left(\sigma_{1}\right)$ から低応力 $\left(\sigma_{2}\right)$ への荷重変動後の繰返し 数, $\Delta a$ は荷重変動後のき裂進展量（いずれも表面での測 定值）である。また，これらの図には比較のため低応力 を一定振幅で繰返した場合のき裂進展挙動も示している. 両図より, いずれの板厚の試験片においても応力下降直 後からき裂進展の遅延が生じているが, 厚板試験片のき 裂はわずかながらも進展しているのに対し, 薄板試験

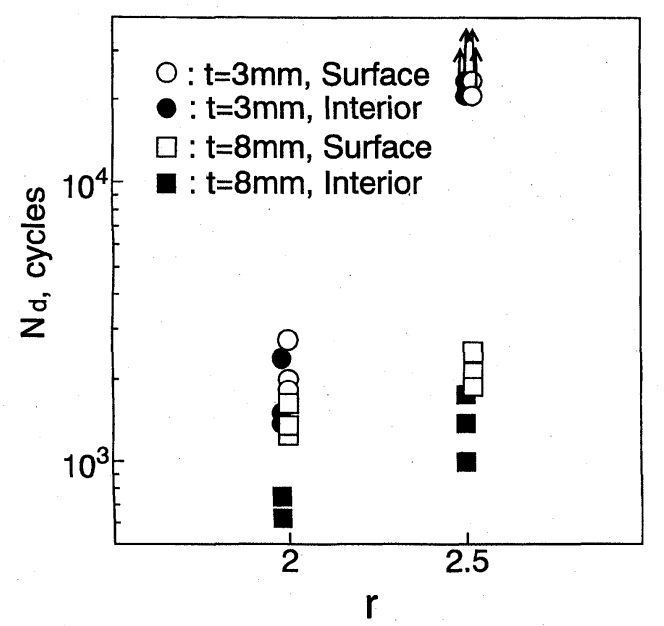

Fig. 7. Effect of specimen thickness on the crack retardation after applying a single peak overload.
片のき裂は完全に停止していることがわかる，このよう に遅延の程度は薄板試験片の方が顕著であることが認め られたが, この傾向は前述の単一過大荷重の場合と一致 する. Fig. 10 は, 板厚 $3 \mathrm{~mm}$ の試験片について, Fig. 8 と同じ負荷条件下での試験片表面と内部における遅延挙 動を比較したものである．試験片内部よりも表面の方が より顕著な遅延を生じていることがわかる.この傾向も 単一過大荷重の場合と同様である.

\section{4 結}

板厚の異なるポリカーボネート板状試験片を用いて, 一定荷重振幅試験, 単一過大荷重試験および二段二重変 動荷重試験を実施し, 疲労き裂進展挙動に及ぼす板厚の 影響を検討した。 得られた結果を要約すると次のように なる.

1) 一定荷重振幅下の疲労き裂進展速度は, 低 $\Delta K$ 領 域において板厚の減少とともに低下する.

2）試験片表面でのひずみゲージ法により検出される き裂開閉口挙動は試験片板厚の影響をほとんど受けない.

3）試験片表面層に形成されるせん断縁の板厚に占め

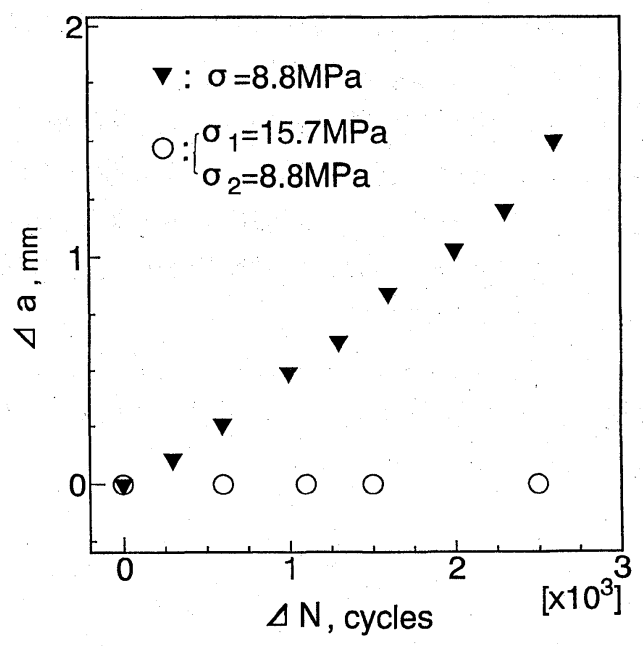

Fig. 8. Crack retardation on the specimen surface under two-step loading in 3mm thick specimen.

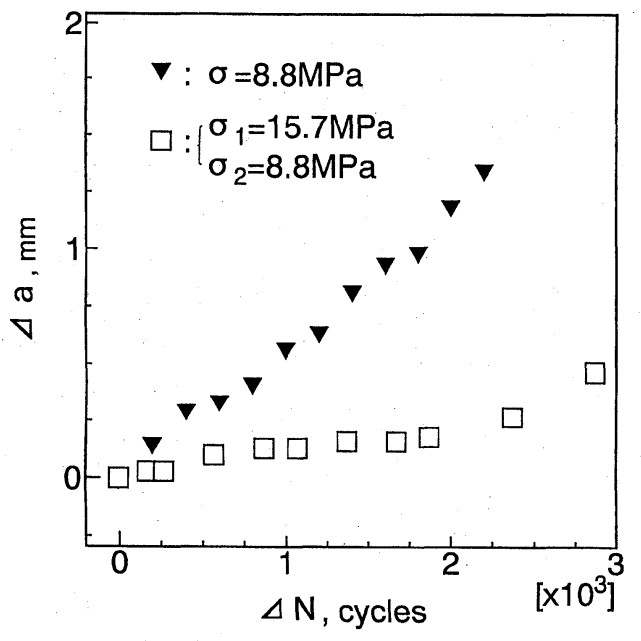

Fig. 9. Crack retardation on the specimen surface under two-step loading in $8 \mathrm{~mm}$ thick specimen. 


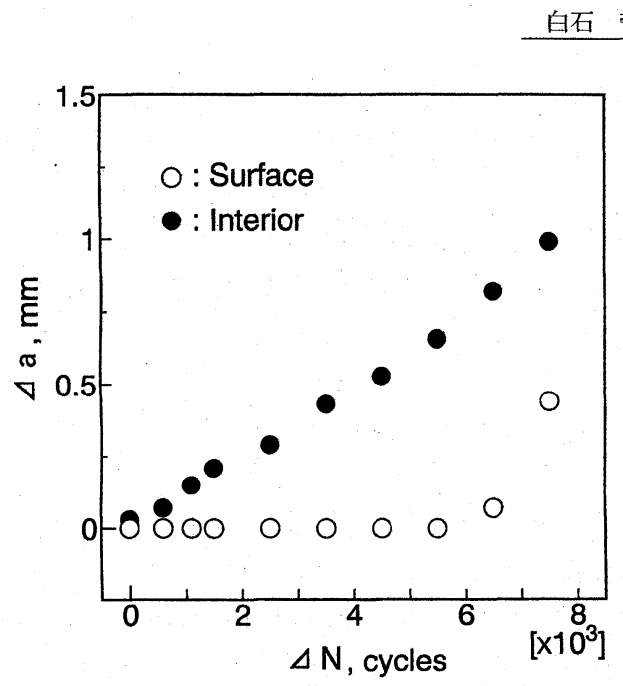

Fig. 10. Crack retardation both on the surface and in the interior of the specimen under two-step loading in $3 \mathrm{~mm}$ thick specimen.

る割合は試験片板厚の減少とともに増大する，上記のよ うな疲労き裂進展速度の板厚依存性はこのようなせん断 縁の形成に起因しているものと理解される.

4）単一過大荷重負荷時に生じるき裂進展量（加速進 展量）は板厚の薄い場合の方がより小さい.この結果も せん断縁の影響によるものと思われる。

5) 単一過大荷重負荷後あるいは二段二重の応力下降 後に生じるき裂進展の遅延挙動に対しても板厚依存性が 認められる.すなわち, 薄い試験片の方が遅延の程度が 大きく, また同一板厚の場合, 試験片表面での遅延の方 が内部でのそれより顕著である.

終わりに，本研究を行うにあたり，実験に協力された 当時愛媛大学工学部学生の金集弘明君, 水野宽人君に感 謝の意を表します。
参 考 文 献

1) R. WHertzberg, "DEFORMATION AND FRACTURE MECHANICS OF ENGINEERING MATERIALS”, p.579 (1989) John Wiley \& Sons.

2 ) 白石哲郎, 曽山義朗, 森慎之助, 材料, 34, 406 (1985).

3) 白石哲郎, 兽山義朗, 森慎之助, 材料, 35, 152 (1986).

4) T. Shiraishi and Y. Soyama, "FATIGUE CRACK ACCELERATION AND RETARDATION IN GLASSY POLYMERS DUE TO A SINGLE PEAK OVERLOAD”, Proc. KSME/ JSME Joint Conf., FRACTURE AND STRENGTH '90, 370 (1990).

5) 白石哲郎, 森 慎之助, 曽山義朗, 材料, 39,933 (1990).

6) M. Parvin and J. G. Williams, Int. J. Frac., 11, 963 (1975).

7 ）成沢郁夫, “高分子材料強度学” (横堀武夫監修), p.189 (1982) オーム社.

$8)$ G. Pitman and I. M. Ward, J. Mat. Sci., 15, 635 (1980).

9) L. P. Pook, Int. J. Frac. Mech., 4, 295(1968).

10) 戸梶恵郎, 安藤善司, 森川邦彦, 材料, 29, 808 (1980).

11) W. Elber, ASTM STP486, 230 (1971).

12）白石哲郎, 黒島俊哉, 曽山義朗, 材料, 37, 795 (1988).

13) 白石哲郎, 荻山博之, 佃 等, 材料, 46, 1255 (1997).

14) F. J. Pitoniak, A. F. Grandt, L. T. Montulli and P. F. Packman, Engng. Fract. Mech., 6, 663 (1974).

15) D. H. Banasiak, A. F. Grandt and L. T. Montulli, J. Appl. Polym. Sci., 21, 1297 (1977).

16) Y. W. Mai, Int. J. Frac., 15, R103 (1979).

17) Y. Imai, T. Takase and K. Nakano, J. Mater. Sci., 24, 3289 (1989).

18) 戸梶恵郎, 安藤善司, 今井利雄, 森川邦彦, 材料, $\mathbf{3 1}$, 51 (1982). 